ISSN 0258-7122 (Print), 2408-8293 (Online)

Bangladesh J. Agril. Res. 43(2): 281-288, June 2018

\title{
RESPONSE OF HYBRID MAIZE TO BORON APPLICATION
}

\author{
M. S. RAHMAN ${ }^{1}$, M. T. ISLAM ${ }^{2}$, S. ISHTIAQUE ${ }^{3}$ \\ M. J. U. SARKER ${ }^{4}$ AND A. S. M. M. R. KHAN ${ }^{5}$
}

\begin{abstract}
An experiment was carried out at farmer's field of Kushtia district under High Ganges River Floodplain Soil (AEZ-11) during Rabi seasons of 2013-14, 2014 15 and 2015-16. The objectives of the study were to evaluate the effect of boron on the yield of hybrid maize (cv. BARI Hybrid Bhutta-9) and to find out the optimum dose of boron for higher yield and economic return. There were 6 treatments comprising 6 levels $\left(0,0.5,1.0,1.5,2.0\right.$ and $\left.2.5 \mathrm{~kg} \mathrm{~B} \mathrm{ha}^{-1}\right)$ of boron along with a blanket dose of $\mathrm{N}_{256} \mathrm{P}_{65} \mathrm{~K}_{45} \mathrm{~S}_{27} \mathrm{Zn}_{3} \mathrm{~kg} \mathrm{ha}^{-1}$ and cowdung 5 tha $^{-1}$. Boron fertility of the initial soil was in medium level $\left(0.33 \mu \mathrm{g} \mathrm{g}^{-1}\right)$. The experiment was conducted in RCB design with three compact replications. Results of three years study revealed that hybrid maize responded significantly to added boron for the first two years but for the third year the effect was statistically non significant. The highest grain yield was obtained with $2.5 \mathrm{~kg} \mathrm{~B}$ ha-1, which was marginally significant with boron control but statistically identical to rest of the boron levels. Although, the yield increased linearly up to $2.5 \mathrm{~kg} \mathrm{ha}^{-1}$ but the effect was relatively better fitted with quadratic response function $\left(\mathrm{R}^{2}=0.943\right)$. The mean highest grain yield found to be $8.55 \mathrm{t} \mathrm{ha}^{-1}$ for $2.5 \mathrm{~kg} \mathrm{~B} \mathrm{ha}^{-1}$ against $8.20 \mathrm{t} \mathrm{ha}^{-1}$ from $0.5 \mathrm{~kg} \mathrm{~B} \mathrm{ha}^{-1}$ and $7.84 \mathrm{t} \mathrm{ha}^{-1}$ from boron control. Considering the boron fertilty of soil, response of maize to boron and economic return, the optimum dose of boron may be $0.5 \mathrm{~kg} \mathrm{ha}^{-1}$ for the cultivation of hybrid maize for medium level boron fertile soil under AEZ-11 of Kushtia district or alike.
\end{abstract}

Keywords: Response, maize, boron, yield, return, MBCR.

\section{Introduction}

Maize (Zea mays L.) is the most important silage plants in the world because of its high yield, high energy forage produced with lower labor and machinery requirements than other forage crops (Roth et al., 1995). Many environmental, cultural and genetic factors influence maize forage yield and quality. In Bangladesh, maize is cultivated mainly for grain; the agricultural area devoted annually to maize was 334975 hectare which was about $2.75 \%$ of cereal cultivating area and average grain production was 2445578 metric ton with an

${ }^{1}$ Senior Scientific Officer, Agricultural Economics, Regional Agricultural Research Station, Bangladesh Agricultural Research Institute (BARI), Jessore; ${ }^{2}$ Scientific Officer, Pomology Division, Horticulture Research Centre, BARI, Gazipur; ${ }^{3}$ Scientific Officer, On-Farm Research Division (OFRD), BARI, Gazipur; ${ }^{4}$ Former Director (T\&C), BARI, Gazipur; ${ }^{5}$ Chief Scientific Officer, On-Farm Research Division (OFRD), BARI, Gazipur, Bangladesh. 
average yield of $7.30 \mathrm{t} \mathrm{ha}^{-1}$ during the year 2015-16 (BBS, 2017). For its high yielding capacity and diversified uses, demand of maize is increasing day by day in the world as well as in Bangladesh. It is now widely used in the poultry farms as animal feed, as well as the people consume roasted and fried maize in Bangladesh. Maize has an immense potential to reduce shortage of food, poultry feed and malnutrition. Because, it is a high yielding and low- cost crop compared to rice and wheat (Rahman, 2011).

Bangladesh Agricultural Research Institute (BARI) has been conducting research activities for varietal development of maize since 1960. Initially, thrust was given for development of composite varieties. So far, BARI has developed seven open pollinated and fifteen hybrid maize varieties. The yield potentiality of the released composite varieties varied from $5.5-7.0$ t/ha and the hybrid varieties ranged 7.4 - $12.0 \mathrm{t} / \mathrm{ha}$ (Rahman, 2011). In Bangladesh, maize farmers cultivate imported commercial hybrid seed (900M, 981, 987, NK 40, Pinnacle, 759, Pioneer-96, Elite, Miracle, Super Gold, Sunshine, Pioneer-V-92 etc.) which is imported by different private seed companies. The grain yield of BARI varieties was lower compared to imported commercial varieties (Khan, et al., 2016; BARI, 2015). Due to tallness of the BARI maize varieties, farmers faced problems with top dressing and intercultural operation (Miah, et al., 2013).

Boron plays an important role in cell-wall synthesis, sugar transport, cell division, differentiation, membrane functioning, root elongation, regulation of plant hormone levels, and generative growth of plants (Marschner, 1995). Boron is taken up as a boric acid, which is translocated slowly within the plant. Deficiency symptoms can include a failure of root tips to elongate, inhibition of DNA and RNA synthesis and inhibition of cell division in the shoot apex of young leaves. Boron is also known to be critical in the elongation of the pollen tube (Salisbury and Ross, 1992). One of the challenges in corn production is its sensitivity to B deficiency (Salisbury and Ross, 1992; Soylu et al., 2004). Boron, a micronutrient, is essential for pollen viability and seed production of crops as well as flowering and fruiting. It also plays vital role in nitrogen metabolism, hormonal action and cell division (BARI, 2006).

Maize has been previously considered to have a relatively low boron (B) requirement as compared to other cereals (Martens and Westermann, 1991). However, based on field responses to B application, its deficiency has been reported in maize across five continents (Bell and Dell, 2008; Shorrocks, 1997; Shorrocks and Blaza, 1973). For example, maize yield increase of $10 \%$ were reported in Rhodesia (now Zimbabwe), up to $26 \%$ in India (Shorrocks and Blaza, 1973), more than $10 \%$ in Switzerland (cited by Mozafar, 1987) and by $9 \%$ in China (Li and Liang, 1997). Deficiency of B in field grown maize was first observed in the 1960s in the United States (Shorrocks and Blaza, 1973), and yield increase of more than $10 \%$ were observed in response to B application (Woodruff et al., 1987). 
Limited studies on B deficiency of various crops including maize suggest a critical soil solution content ranging from $0.15 \mathrm{mg}$ of $\mathrm{B} \mathrm{kg}^{-1}$ to $1.0 \mathrm{mg}$ of $\mathrm{B} \mathrm{kg}^{-1}$ and $2.0 \mathrm{mg} \mathrm{B} \mathrm{kg}^{-1}$ and a critical leaf B concentration of $30 \mathrm{mg} \mathrm{kg}^{-1}$ (FAO, 1990). However, additional studies are needed as soil chemical and physical properties and species selection influence B availability to and uptake by plants possibly resulting in large variability in optimum economic $\mathrm{B}$ rates for various crops and soils.

Sarkaut et al. (2013), Akhter and Mahmud (2009), BARI (2009), Akhter and Khan, 2007 and Singh, 1998 found significant response of hybrid maize to boron application. Akhter and Mahmud, 2009 reported that the yield of maize grain increased significantly due to added boron up to $2.0 \mathrm{~kg} \mathrm{~B}^{-1}$ and yield components like plant height, ear height and straw yield were influenced significantly due to application of boron. Singh (1998) found that Rabi maize gave the optimum yield at $1.5 \mathrm{~kg} \mathrm{ha}^{-1} \mathrm{~B}$ application and Kharif maize produced the best yield at $2.0-2.5 \mathrm{~kg} \mathrm{~B} \mathrm{ha}^{-1}$ rate. Boron application increased maize yield, indicating B deficiency (Gunes et al., 2011).

In mustard, chickpea, mungbean, soybean, groundnut, cauliflower, tomato, papaya and wheat, positive response to boron fertilization were found (Rashid et al., 2012; Hossain et al., 1995; Islam, 2005; Saha et al., 2003; Sinha et al., 1991; Shen et al., 1998). These studies revealed that boron is very important in cell division and in pod and seed formation. Rate of water absorption and carbohydrate transaction is restricted due to boron deficiency. Thus, boron fertilization is necessary for improvement of crop yield and nutritional quality. There is a good scope to introduce hybrid maize with proper management of fertilizer. This will help increase the present production and requirement. The response of hybrid maize to boron has not yet been tested under different agroclimatic conditions especially for calcareous soils under greater Kushtia region. Considering the above perspectives, the present experiment was undertaken to evaluate the effect of boron on the yield of hybrid maize and to findout the optimum dose of B application for the cultivation of hybrid maize with greater economic profitability.

\section{Materials and Methods}

The study was conducted at Multi Location Testing (MLT) site of Kushtia sadar (Latitude: 23.87736 ${ }^{\circ} \mathrm{N}$ Longitude: $89.09126^{\circ} \mathrm{E}$ ) during the periods (November to April) of 2013-14 to 2015-16 at farmers' field condition. Its altitude is $17 \mathrm{~m}$. The average high temperature is $37.8^{\circ} \mathrm{C}$ and the average low is $9.2^{\circ} \mathrm{C}$. Annual rainfall averages 1,467 millimeters. The soil is calcareous in nature under High Ganges River Floodplain (AEZ-11). Before setting up of the experiment, soil samples were collected at depth of $0-15 \mathrm{~cm}$ to determine baseline its properties. Soil samples were air-dried, crushed, and sent to SRDI laboratory for analysis. The nutrient status of initial soil is presented in Table 1. The content of B in the 
initial soil was in medium level $\left(0.33 \mu \mathrm{g} \mathrm{g}^{-1}\right)$. Based on the soil properties, the blanket dose of all nutrients except boron was estimated following FRG, 2012.

Table 1. Chemical properties of initial soil $(0-15 \mathrm{~cm}$ depth) of the experimental field at Bottoil, Kushtia sadar, Kushtia during 2013-14.

\begin{tabular}{|c|c|c|c|c|c|c|c|c|}
\hline \multirow[b]{2}{*}{ Replication } & \multirow[b]{2}{*}{$\mathrm{pH}$} & \multirow{2}{*}{$\begin{array}{c}\text { Organic } \\
\text { matter } \\
(\%)\end{array}$} & \multirow{2}{*}{$\begin{array}{c}\mathrm{K} \\
\mathrm{meq} / 100 \\
\mathrm{~g} \text { soil }\end{array}$} & \multirow{2}{*}{$\begin{array}{l}\text { Total } \\
\mathrm{N}(\%)\end{array}$} & $\mathrm{P}$ & S & $\mathrm{Zn}$ & B \\
\hline & & & & & \multicolumn{4}{|c|}{$\mu g^{-1}$} \\
\hline $\mathrm{R}_{1}$ & 7.8 & 1.87 & 0.24 & 0.09 & 11.70 & 20.40 & 0.72 & 0.34 \\
\hline $\mathrm{R}_{2}$ & 8.1 & 1.88 & 0.27 & 0.10 & 10.70 & 18.21 & 0.74 & 0.31 \\
\hline $\mathrm{R}_{3}$ & 7.9 & 1.82 & 0.28 & 0.09 & 8.80 & 18.40 & 0.72 & 0.35 \\
\hline Mean/Range & $7.8-8.1$ & 1.86 & 0.26 & 0.09 & 10.40 & 19.00 & 0.73 & 0.33 \\
\hline Critical limit & - & - & 0.12 & 0.12 & 10 & 10 & 0.60 & 0.20 \\
\hline Interpretation & $\begin{array}{l}\text { Slightly } \\
\text { Alkaline }\end{array}$ & Medium & Medium & Low & Low & Medium & Low & Medium \\
\hline
\end{tabular}

The experiment was laid out in randomized completely block design with three compact replications. There were 6 levels of B $(0,0.5,1.0,1.5,2.0$ and $2.5 \mathrm{~kg}$ $\mathrm{ha}^{-1}$ ) applied in the form of boric acid. In addition, a blanket dose of $\mathrm{N}_{256} \mathrm{P}_{65} \mathrm{~K}_{45}$ $\mathrm{S}_{27} \mathrm{Zn}_{3} \mathrm{~kg} \mathrm{ha}^{-1}$ was applied in the forms of urea, TSP, MoP, gypsum and zinc oxide. Cowdung was applied @ $5 \mathrm{t} \mathrm{ha}^{-1}$. As such, 6 treatments were used in this study. BARI hybrid butta-9 variety was used as the test crop. The unit plot size was $4 \mathrm{~m}$ x $5 \mathrm{~m}$. Seeds were sown on 20 November, 2013, 07 November, 2014 and 16 November, 2015 with a spacing of $60 \mathrm{~cm} \times 20 \mathrm{~cm}$ and the seed rate was $20 \mathrm{~kg} \mathrm{ha}^{-1}$. All P, K, S, Zn, B and one third of $\mathrm{N}$ were applied as basal dose at the time of final land preparation and the remaining two third of $\mathrm{N}$ was top dressed in two equal splits at 8-10 leaf stage and teaseling stage. Weeding was done two times at 31 days after sowing (DAS) and 51 DAS. The crop was irrigated 4 times at 31, 62, 77 and 103 DAS. Common cutworm was attacked in the maize filed in seedling stage. Dursban was applied in maize field @ $5 \mathrm{ml} \mathrm{L}^{-1}$ of water to control common cutworm. No disease was noticed in the maize field. The maize grain was harvested on 22 April, 2014, 10 April, 2015 and 18 April, 2016. The necessary data on different parameters were recorded from $1 \mathrm{~m}^{2}$ in 3 areas from each treatment. Then it was computed and analyzed statistically using $\mathrm{R}$ package. The analyzed data was adjusted with Least Significant Difference (LSD) test at $5 \%$ level. Per hectare gross return, total variable cost, gross margin and marginal benefit cost ratio (MBCR) was calculated.

\section{Results and Discussion}

\section{Yield components}

There was no significant effect of boron on the yield components like plant height, ear height, number of grain per cob (2015-16) and 100 grain weight 
(except 2013-14) of hybrid maize although a positive trend of improvement was noticed (Table 2). The number of grain per cob increased significantly with the increased rate of boron application up to $2.5 \mathrm{~kg} \mathrm{~B} \mathrm{ha}^{-1}$ during the year 2013-14 and 2014-15. Hundred grains weight increased significantly due to higher boron application during 2013-14. Numerically, the studied parameters showed the highest result with $2.5 \mathrm{~kg} \mathrm{~B} \mathrm{ha}^{-1}$ and the lowest from boron control in most of the cases. The highest plant height was recorded in $\mathrm{T}_{6}$ treatment in all the years except 2014-15 (Table 2). The ear height was the highest in $\mathrm{T}_{6}$ treatment during 2013-14 and 2014-15. Numbers of grain per cob and 100 grain weight were maximum in $\mathrm{T}_{6}$ treatment in all the year. Similar positive responses were found by Sarkaut, et al., 2013; Gunes et al., 2011; Akhter and Mahmud, 2009; Akhter and Khan, 2007 and Singh, 1998.

\section{Grain yield}

The yield of hybrid maize responded significantly to added boron for the first 2 years of the study but in the third year the effect was statistically non significant (Table 2). Residual effect of boron for a medium B fertile soil might have resulted in non-significant effect. However, the highest grain yield (8.40 and $8.77 \mathrm{t}$ ha-1 for 2013-14 and 2014-15, respectively) was obtained with $2.5 \mathrm{~kg}$ B ha-1, which was narrowly $(\mathrm{p}>0.05$ ) significant with boron control but statistically identical to rest of the boron levels. The mean highest grain yield $\left(8.55\right.$ tha $\left.^{-1}\right)$ was found in $T_{6}$ and the lowest yield $\left(7.84\right.$ tha $\left.^{-1}\right)$ was in $T_{1}$. In fact, the yield of hybrid maize in $\mathrm{T}_{6}$ was 9 percent higher than that of $\mathrm{T}_{1}$. Boron fertility of initial soil was in medium level, which in presence of added cowdung might have resulted in relatively lower contribution of boron to the yield of hybrid maize. The yield was the highest in $\mathrm{T}_{6}$ treatment due to its higher number of grain per cob and 100 grain weight. For straw yield, the effect of B showed similar trend although it was statistically non-significant. Similar findings of positive response were reported by Sarkaut et al. (2013), Gunes et al. (2011), Akhter and Mahmud (2009), Akhter and Khan (2007) and Singh (1998).

\section{Cost and return of maize}

The cost of maize cultivation for different treatments is shown in Table 3 . The average highest gross return (Tk. $\left.147249 \mathrm{ha}^{-1}\right)$ was obtained from $\mathrm{T}_{6}(2.5 \mathrm{~kg} \mathrm{~B}$ $\mathrm{ha}^{-1}$ ). About 8.83 percent more return was found in $\mathrm{T}_{6}$ treatment compared to $\mathrm{T}_{1}$. The average highest total variable cost (Tk. $80942 \mathrm{ha}^{-1}$ ) was calculated on $\mathrm{T}_{6}$. As a result, the average gross margin was also the highest in $\mathrm{T}_{6}$ treatment (Tk. 66277 $\mathrm{ha}^{-1}$ ). The marginal benefit cost ratios (MBCR) found to be positive and varied from 4.47 to 11.45. The highest MBCR (11.45) was obtained from $\mathrm{T}_{2}$ treatment $\left(0.5 \mathrm{~kg} \mathrm{~B} \mathrm{ha}^{-1}\right)$ indicating that it was the most economically viable treatment among all other treatments. 
RAHMAN et al.
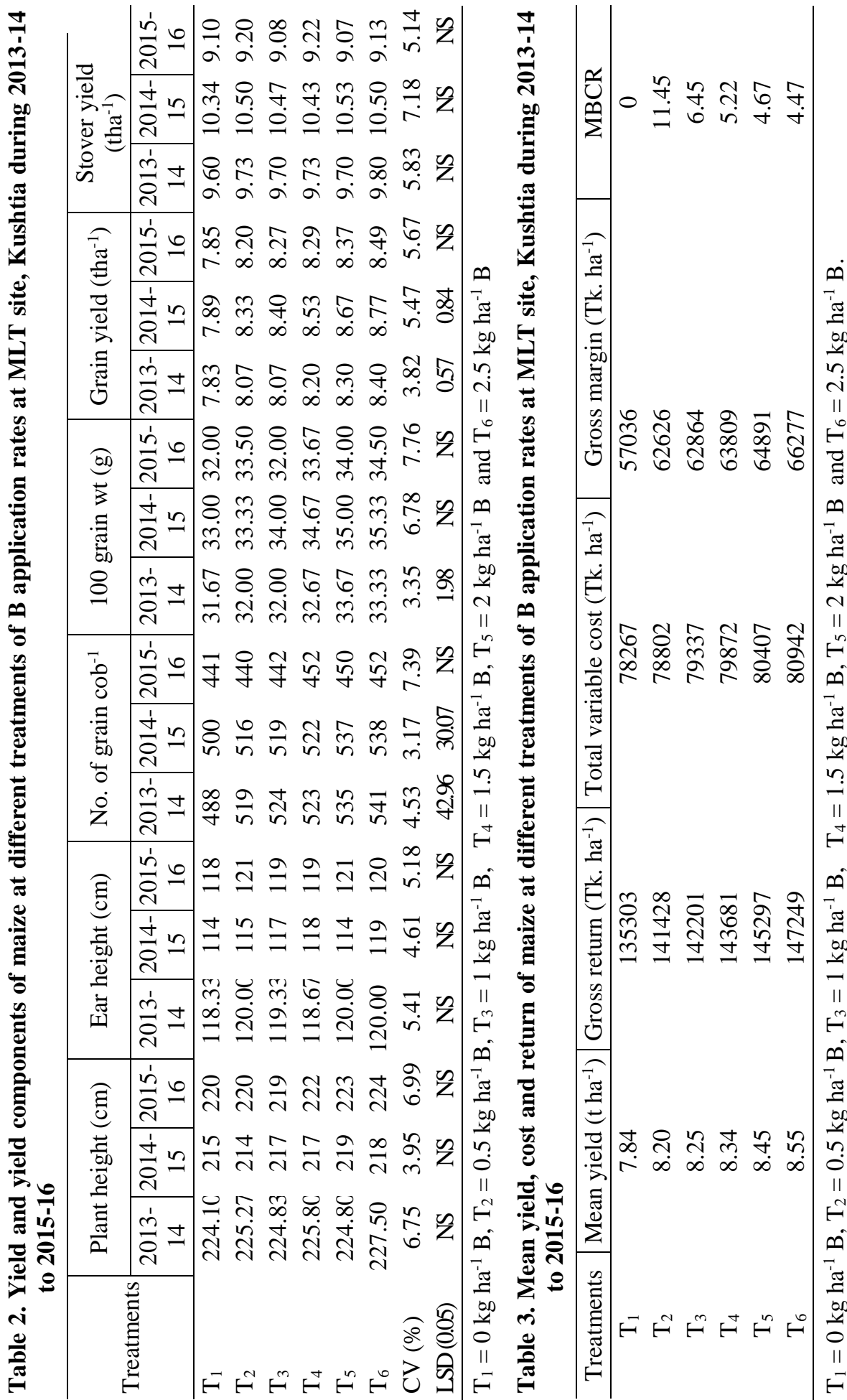


\section{Conclusion}

Considering the boron fertilty of soil, maize response to boron and economic return, it can be concluded that boron played significant role in augmenting the yield of hybrid maize and the optimum dose of boron may be $0.5 \mathrm{~kg} \mathrm{ha}^{-1}$ for the study area. Therefore, for medium level boron fertile soil under AEZ-11 of Kushtia district or alike, application of $0.5 \mathrm{~kg} \mathrm{~B} \mathrm{ha}^{-1}$ may be recommended for the cultivation of hybrid maize. Besides, a blanket dose of other nutrients $\left(\mathrm{N}_{256}\right.$ $\mathrm{P}_{65} \mathrm{~K}_{45} \mathrm{~S}_{27} \mathrm{Zn}_{3} \mathrm{~kg} \mathrm{ha}^{-1}$ and cowdung $5 \mathrm{t} \mathrm{ha}^{-1}$ ) should also be applied on the basis of soil test following FRG -2012.

\section{References}

Akhter, Sohela and M. S. Khan. 2007. Response of hybrid maize to boron and lime. Booklet. Soil Science Division, Bangladesh Agricultural Research Institute, Joydebpur, Gazipur-1701.

Akhter, Sohela and N. U. Mahmud. 2009. Response of hybrid maize to boron and lime. Annual Research Report, 2008-09. Soil Science Division, Bangladesh Agricultural Research Institute, Joydebpur, Gazipur-1701. Pp. 244-253.

BARI (Bangladesh Agricultural Research Institute). 2006. Annual Research Report, 2005-2006, Soil Science Division. Bangladesh Agricultural Research Institute, Joydebpur, Gazipur-1701.

BARI (Bangladesh Agricultural Research Institute). 2009. Response of hybrid maize to boron and lime. Annual Report (2008-09), BARI, Joydebpur. Pp. 309-310.

BARI (Bangladesh Agricultural Research Institute). 2015. Comparative yield trial of imported and local maize hybrids, Annual Report (2014-15), BARI, Joydebpur. P. 35.

BBS. 2017. The Year Book of Agricultural Statistics of Bangladesh, Statistics Division, Ministry of Planning, Dhaka, Bangladesh.

Bell R. W. and B. Dell. 2008. Micronutrients for sustainable food, feed, fiber and bioenergy production. International Fertilizer Industry Association. Paris, France.

FAO. 1990. Micronutrient. Assessment at the country leaves an international study. FAO Soils Bulletion 63. Rome.

Gunes A., N. Ataoglu, A. Esringu, O. Uzun, S. Ata and M. Tarun. 2011. Yield and chemical composition of corn (Zea Mays L.) as affected by boron management. International Journal of Plant, Animal and Environmental Sciences, Vol. 1, Issue-1: $42-53$.

Hossain, M. A., M. Jahiruddin and F. Khatun. 1995. Response of wheat and mustard to manganese, zinc and boron in Calcareous Soil. Bangladesh J. Crop Sci. 6 (1\&2): 51-56.

Islam, M. B. 2005. Requirement of boron for mustard, wheat, and chickpea based rice cropping patterns. Ph. D. Dissertation, Department of Soil Sci. Bangladesh Agricultural University, Mymensingh.

Khan, A. S. M. M. R., M. S. Rahman, M. K. U. Ahammad, M. F. Hossain, M. A. Salam, S. Mondal and M. T. Islam. 2016. Annual Research Report 2015-16, Mujibnagar Integrated Agricultural Development Project, On-Farm Research Division, Bangladesh Agricultural Research Institute, Kushtia. Pp. 66-69.

Li Y. and H. Liang. 1997. Soil boron content and the effect of boron application on yield of maize, soybean, rice and sugarbeet in Heilonjiang province, PR China. In: Bell R 
W, Rerkasem B (eds) Boron in soils and plants. Kluwer, Dordrecht, the Netherlands, Pp 17-21.

Marschner, H. 1995. Mineral nutrition of higher plants.Second edition. 889pp. London: Academic Press

Martens, D. C. and D. T. Westermann. 1991. Fertilizer applications for correcting micronutrients deficiencies. In: Mortvedt, J. J., ed. Micronutrients in agriculture. Second Edition SSSA. Madison. Chapter 15. P. 549-592.

Miah, M. A. Monayem, T. M. B. Hossain, M. A. Matin, S. Hossain, Moniruzzaman and R. Kumar. 2013. Assessments of the maize situation, outlook and investment opportunity to ensure food security in Bangladesh. Bangladesh Agricultural Research Institute (BARI), Joydebpur, Gazipur 1701, Bangladesh. Indian council of Agricultural Research (ICAR), Hyderabad, Andrapradesh, India. Pp. 114.

Mozafar, A. 1987. Effect of boron on ear formation and yield components of two maize (Zea mays L.) hybrids. Journal Plant Nutrition. 10: 319-332.

Rahman, M. S. 2011. Productivity and sustainability of maize in Bangladesh: Prospects and potentials. Un-published $\mathrm{Ph}$. D. dissertation. Department of Agricultural Economics, Bangladesh Agricultural University, Mymensingh.

Rashid, M. H., M. M. Hasan, M. Ahmed, M. T. Rahman and K. A. M. M. Rahman. 2012. Response of mustard to boron fertilization. Bangladesh J. Agril. Res. 37(4): 677-682.

Roth, G., D. Undersander, M. Allen, S. Ford, J. Harrison. and C. Hunt. 1995. Corn Silage Production, Management, and Feeding. ASA, Madison, WI. NCR574.

Saha, P. K., M. A. Saleque., S. K. Zaman and N. J. Bhuiyan . 2003. Response of mustard to S, Zn, and B in Calcareous Soil. Bangladesh J. Agril. Res. 28(4): 633-636.

Salisbury, F. B. and C. W. Ross. 1992. Plant Physiology $4^{\text {th }}$ Edition. Wadsworth Publishing Company, USA.

Sarkaut, S., S. Moradi, K. A. Nezhad and A. R. Abdola. 2013. Growth and yield response of maize (Zea mays L.cv. SC704) to different rates of potassium and boron. Intl. J Agri Crop Sci. Vol., 5 (3): 236-240.

Shen, K., Z. G. Shen and Q. Y. Hung. 1998. A study of boron nutrition and seed setting in rape (B. napus). Acta Agronomic Sinica 19: 539-545.

Shorrocks, V. M. 1997. The occurrence and correction of boron deficiency. Plant and Soil 193: 121-148.

Shorrocks, V. M. and A. J. Blaza. 1973. The boron nutrition of maize. Field Crop 25: 25-27.

Singh, A. P. 1998. Indian Fert. Science. Annual 1.26.

Sinha, R. B., R. Sakal., A. P. Singh and N.S. Bhogal. 1991. Response of some field crops to boron application in Calcareous Soil. J. Indian. Soc. Soil Sci. 39(1): 118-122.

Soylu, S., A. Topal, B. Sade, N. Akgun, S. Gezgin and M. Babaoglu. 2004. Yield and yield attributes of durum wheat genotypes as affected by boron application in borondeficient calcareous soils: an evaluation of major Turkish genotypes for boron efficiency. J. Plant Nutr. 27(6): 1077-1106. https://doi.org/10.1081/PLN-120037537

Woodruff, J. R., F. W. Moore, and H. L. Musen. 1987. Potassium, boron, nitrogen and lime effects on corn yield and ear leaf nutrients concentration. Agronomy Journal, 79: $520-524$. 